seven days. ${ }^{1}$ In addition, there is an ancient practice in yogic art termed Khecari $M u d r \bar{a},{ }^{2}$ where the position of the tongue is designed to awaken spiritual energies in the body by stimulation of pituitary and pineal glands. Considered as the best of all the Mudras, people are trained to place the tip of the tongue on the uvula or in the nasal cavity behind the uvula.

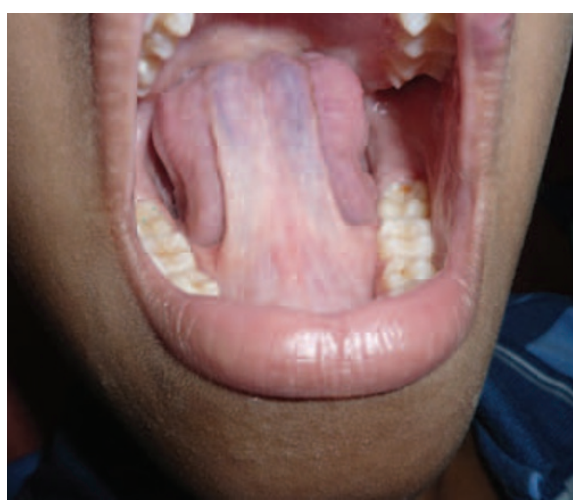

Fig. 1 Open wide..

S. Surendran, E. Thomas,

Chennai

S. Asokan,

Tiruchengode

1. Cincik H, Cekin E, Gungor A, Poyrazoglu E. Does a hyperflexible tongue cause snoring? Internet J Otorhinolaryngol 2005: 3(2).

2. Definition of Khecarī Mudrā. Wikipedia. http:// en.wikipedia.org/wiki/Khecarī_mudrā

DOI: 10.1038/sj.bdj.2012.54

\section{A CURIOUS PARADOX}

Sir, the recent letter and articles by Kelleher $^{1-3}$ and the recent case reports in the $B D J^{4,5}$ which have featured veneers and all ceramic crowns have provided significant food for thought and raise some interesting questions.

The provision of ceramic crowns or veneers can result in prettier 'cosmetic' results which are likely to be met with some satisfaction by the patient. The question needs to be asked whether this treatment is unnecessarily damaging, both biologically and structurally, to the remaining healthy tooth tissue? The long term clinical justification for the removal of significant amounts of existing remaining sound tooth structure, particularly in patients who already suffer with tooth surface loss, always seems a curious paradox to me.

Like many others, I am concerned that the current popularity of cosmetic dentistry seems now to have dominated 'sects' or 'cosmetic cults' to the point where the professional status of dentistry could be threatened. The combined drivers of financial incentives for the 'cosmetic' clinician, the patient's undoubted desire for an improved dental appearance, coupled with demand for immediate gratification of both parties, could result in a shift away from dental 'health' as the priority. The current growth of cosmetic dentistry has created a situation that could result in an epidemic of iatrogenically induced co-morbidities that will impact on patients and their future dentists for many years to come. of course patients are 'fully' consenting adults, but to what extent is this consent 'fully' informed?

The recent Adult Dental Health Survey ${ }^{6}$ identified a cohort of patients with extensively restored teeth in their 50 s and 60s, the so called 'heavy metal generation' who will require increasingly complex restorative support as they age. The future needs of the current generation of allegedly 'cosmetic' patients, whose teeth have been irreversibly damaged in order to provide elective ceramic restorations, can only be ignored by the most short-sighted of clinicians.

We as a profession are, just about, still regarded as traditional reliable professionals as are most doctors and lawyers. Electively destructive procedures, conveniently couched as 'cosmetic' treatment, with no significant long term health gain, involve real risk to patients and to our professional status. In dentistry is the "customer always right'? Hairdressers cut and colour hair which requires significant skill, can change the appearance for better, or sometimes worse, but the customer can usually sit comfortably in the knowledge that their hair will eventually grow back.

One absolute certainty is that the healthy enamel and dentine that disappear up the suction tube will never return. In contrast the negative consequences of elective 'cosmetic dentistry' may remain with the patient forever and can potentially damage the patientdentist relationship. ${ }^{3}$
Sadly, engagement of an air rotor inevitably means you are married to the subsequent problems.

\section{A. Alani,} Newcastle

1. Kelleher M. Abuse of dental privilege. Br Dent J 2011; 211: 347.

2. Kelleher M G D. The 'Daughter Test' in aesthetic ('esthetic') or cosmetic dentistry. Dent Update 2010; 37: 5-11.

3. Kelleher M. Porcelain pornography. Faculty Dent J 2011; 2: 134-141. Available at www.rcseng.ac.uk/ news/docs/Kelleher Veneers 5 July 2011.pdf

4. Mizrahi B. All-ceramic silica/glass-based crowns clinical protocols. Br Dent J 2011; 211: 257-262.

5. Rickman L J, Padipatvuthikul P, Chee B. Clinical applications of preheated hybrid resin composite. BrDent J 2011; 211: 63-67.

6. NHS: The Information Centre for health and social care. Adult Dental Health Survey 2009 - Summary report and thematic series. 24 March 2011 Available at: http://www.ic.nhs.uk/statisticsand-data-collections/primary-care/dentistry/ adult-dental-health-survey-2009--summaryreport-and-thematic-series

DOI: $10.1038 /$ sj.bdj.2012.55

\section{OLFACTORY ASSAULT}

Sir, I write in response to P. R. Williams' letter (BDJ 2011; 211: 397). Throughout my career I have often heard of people wearing dentures constantly for several years, often because instructions to the contrary were never made.

I had never experienced such a case until I saw a patient on an emergency clinic in 2000. It transpired she had been wearing her upper partial denture constantly for 14 years, since 1986.

You can only imagine the assault on the visual and olfactory senses when I removed it to examine her mouth!

R. Kitchen,

Bristol

DOI: 10.1038/sj.bdj.2012.56

\section{INTER-PROXIMAL DAMAGE}

Sir, Dr Kelleher is right to be concerned about over-prescription of veneering techniques. ${ }^{1}$ Over-prescription of any treatment modality is inappropriate. Criminal damage is criminal damage and should be dealt with accordingly. He is also right to emphasise the potential for composite resin based solutions for anterior teeth aesthetic issues.

Dr Kelleher is, however, wrong, and in a sense abusing privilege himself, to continue to polarise discussion by over-demonising veneer provision. Ceramics are generally more aesthetic and longer lasting than composite resins. There is a much more interest- 
ing discussion to have about ceramic veneers than just condemning them. How well can they be done? How long can they last and what are the factors that contribute to this? ${ }^{2}$ I have placed and otherwise observed veneers that have lasted 15 years and more and then some do not last nearly so long. I do see them gradually develop stress fractures, sometimes mimicking abfraction and stress breakdown in natural tooth tissue. If appropriately provided they work well, rarely displace and the levels of patient satisfaction can be very high.

For example I placed a veneer on my daughter's UL2 eight years ago. She is very happy with it and she is aware that it is a 'repeat prescription' treatment. I suspect it will last at least another ten years.

If Dr Kelleher is really so concerned about enamel 'hacking' he could be much more concerned at the catastrophic iatrogenic damage done to inter-proximal surfaces of adjacent teeth during routine dental treatments. Dentists are very poor at preparing inter-proximal cavities for restoration without damaging the adjacent tooth. Some research ${ }^{3}$ suggests that this occurs in up to $70 \%$ of inter-proximal preparations. There seems to be a conspiracy not to acknowledge this. At least with inappropriate veneering the culprit can be identified. With inter-proximal enamel damage it can take several years for caries to develop within the un-cleansable iatrogenic cavitation and is very unlikely to be associated with the dentistry that caused it.

Opinion posturing and position taking is important for the profession to discuss and understand itself and its impact, but it should be relevant and proportionate. I suggest that elective enamel preparation in veneer preparation is the tip of the iceberg in the damage that operative dentistry really causes. The easy target of elective criminal 'bad' cosmetic surgery detracts from serious discussion about the total damage that is caused by the honest intention of 'good' routine dentistry.

D. English, Norwich
1. Kelleher M. Abuse of dental privilege. Br Dent J 2011; 211: 347.

2. Magne P, Belser U (eds). Bonded porcelain restorations in the anterior dentition: a biomimetic approach. Quintessence Publishing Co, 2002.

3. Qvist V, Johanessen L, Bruun M. Progression of approximal caries in relation to iatrogenic preparation damage. J Dent Res 1992; 71: 1370-1373.

DOI: 10.1038/sj.bdj.2012.57

\section{AMALGAM AND CREMATORIA}

Sir, I trained at the Royal London Hospital and qualified as an RDSA in the 1980s but for the last five years I have been employed by the funeral profession and I am studying for my Dip FD. I have spent some time at two crematoria to complete one of my modules, the last question of which pertains to improvements I could suggest.

Mercury emissions and combating the damage these do to the atmosphere definitely increases the cost of a cremation financially. The government, following the European guidelines, has requested that crematoria do everything to reduce these emissions by $50 \%$ by the end of 2012. Mercury emissions abatement systems have to be fitted into every crematorium at huge cost that would have to be passed onto the clients. I do understand these systems protect the environment from the release of other gases as well as mercury.

More often than not the elderly of today die without teeth. The problem is going to get a lot worse when my generation (born in the 1960s) pass away as we have our teeth and often well filled. A cremation cannot go ahead if the deceased has a pacemaker, radioactive device or an intramedullary nailing system. These have to be removed. Could we not consider removing teeth filled with amalgam during a post mortem or embalming, knowing as we do the damage caused to the environment that leaving them in place would cause? It is a consideration that I think the public should be made aware of and I would value the thoughts of your readers.

\section{Robinson}

By email

DOI: 10.1038/sj.bdj.2012.58 